\title{
A study of GluK1 kainate receptor polymorphisms in Down syndrome reveals allelic non-disjunction at $1173(\mathrm{C} / \mathrm{T})$
}

\author{
Debarati Ghosh $^{\mathrm{a}, \mathrm{b}}$, Swagata Sinha ${ }^{\mathrm{b}}$, Anindita Chatterjee ${ }^{\mathrm{b}}$ and Krishnadas Nandagopal ${ }^{\mathrm{a}, \mathrm{b}, *}$ \\ ${ }^{a}$ Manovikas Biomedical Research \& Diagnostic Centre, 482 Madudah, Plot I-24, Sector-J, Eastern Metropolitan \\ Bypass, Kolkata-700107, India \\ ${ }^{\mathrm{b}}$ Manovikas Kendra Rehabilitation \& Research Institute for the Handicapped, 482 Madudah, Plot I-24, Sector-J, \\ Eastern Metropolitan Bypass, Kolkata-700107, India
}

\begin{abstract}
Mechanisms underlying Down syndrome (DS)-related mental retardation (MR) remain poorly understood. In trisomic offspring, non-disjunction may result in the reduction to homozygosity of a susceptibility allele inherited from a heterozygous parent. Accordingly, we sought evidence for allelic non-disjunction in the GluK1 gene that encodes the critical kainite-binding glutamate receptor subunit-5, maps to chromosome 21q22.1 in the DS critical region and is expressed in brain regions responsible for learning and memory. Three polymorphisms of GluK1 [522(A/C) rs363538; 1173(C/T) rs363430 and 2705(T/C) rs363504] were genotyped in 86 DS patient families by means of PCR-coupled RFLP assays and evaluated with respect to allele frequency, heterozygosity, linkage disequilibrium, stage and parental origin of allelic non-disjunction. We report that the distribution of allele frequencies is in Hardy-Weinberg equilibrium. Moderate heterozygosity (0.339) and a major allele frequency of 0.78 render the $1173(\mathrm{C} / \mathrm{T})$ marker informative. Pair-wise comparisons reveal that $522(\mathrm{~A} / \mathrm{C})-1173(\mathrm{C} / \mathrm{T})\left[\chi^{2}=31.2, d f=1, p=0.0001\right.$; $\left.D^{\prime}=0.42\right]$ and $1173(\mathrm{C} / \mathrm{T})-2705(\mathrm{~T} / \mathrm{C})\left[\chi^{2}=18.3, d f=1, p=0.0001 ; D^{\prime}=0.34\right]$ are in significant linkage disequilibrium of weak magnitude. The estimated ratio of meiosis-I to meiosis-II errors arising from allelic non-disjunction of $1173(\mathrm{C} / \mathrm{T})$ is $4: 1$ in maternal cases and 2:1 in paternal cases. Studies including additional markers and patient samples are warranted to further substantiate present findings.
\end{abstract}

Keywords: Down syndrome, mental retardation, glutamate, GluK1/GluR5/GRIK1, allelic non-disjunction, parent and stage of origin, risk

\section{Introduction}

Down syndrome (DS) occurs due to non-disjunction of chromosome 21 and is the leading genetic cause of mental retardation $(\mathrm{MR})[12,27,33]$. Other than the presence of an additional chromosome, factors such as allelic variation in candidate genes for MR may al-

*Corresponding author: Krishnadas Nandagopal, Ph.D., Manovikas Biomedical Research \& Diagnostic Centre, Manovikas Kendra Rehabilitation \& Research Institute for the Handicapped, 482 Madudah, Plot I-24, Sector-J, Eastern Metropolitan Bypass, Kolkata700107, India. Tel.: +91 03340012732 extn. 235; Fax: +91 033 2442 8275; E-mail: knandago@yahoo.com. so contribute to the complex phenotype. Accordingly, dosage imbalance of alleles that have been triplicated or the variable penetrance of alleles in a critical region of chromosome $21 \mathrm{q}$ have been postulated to account for the range of MR and observed developmental delay in DS [30]. In the case of trisomic offspring, nondisjunction may also result in the reduction to homozygosity of a susceptibility allele inherited from a heterozygous parent [20]. Given a central role for the neurotransmitter glutamate in mediating physiological processes such as learning, memory and neuronal plasticity [13] we reasoned that polymorphic markers implicated in excitatory glutamatergic neurotransmission are 


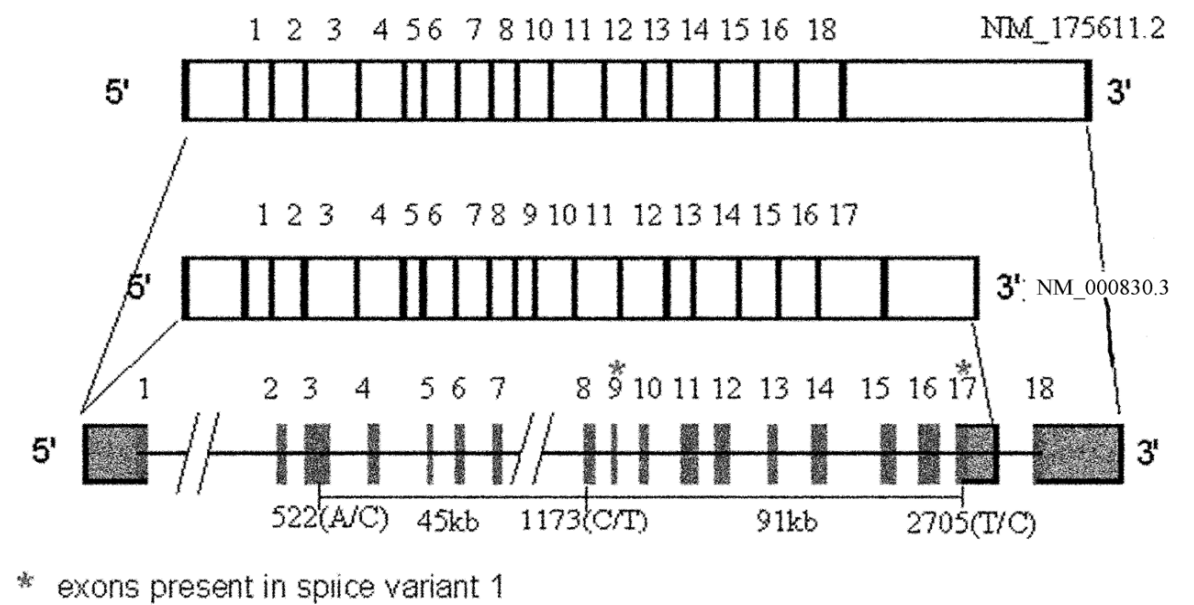

Fig. 1. A schematic representation of the GluK1 gene showing position and relative physical distance between 522(A/C), 1173(C/T) and 2705(T/C) polymorphisms in the alternatively spliced variants NM_175611.2 and NM_000830.3.

likely to influence genetic susceptibility to DS-related MR.

The human GluK1/GRIK1/GluR5 gene codes for the critical subunit-5 of glutamate receptors that bind kainate [1,7], maps to chromosome 21q22.1 [17] and spans $400 \mathrm{~kb}$ with 18 exons [1] (Fig. 1). GluK1containing glutamate receptors form $\mathrm{Ca}^{2+}$ channels [2] that are expressed in the hippocampus, cerebellum and cortex [13]. Robust expression of GluK1 mRNA is observed in cortical layers II, III and IV, with a transient peak during the period of greatest developmental plasticity in the somatosensory cortex of rat brain [6,28]. A search of human (T1Dbase) [3,23] and murine (Gene Novartis Foundation) [3] databases reveals region-specific expression of GluK1 mRNA in the cerebellum, striatum, caudate nucleus, hippocampus, amygdala and the cortex.

Since genetic variation in GluK1 may impact behavioral phenotypes [26], we elected to study the role of three commonly reported single nucleotide polymorphisms (SNP) of GluK1 in mediating susceptibility to DS-related MR. The 522(A/C) [rs363538] transversion in exon 3 and the $1173(\mathrm{C} / \mathrm{T})$ [rs363430] transition in exon 8 result in conservative changes in the codons for the amino-acid residues T174 and D391, respectively [25]. These residues are located in the extra-cellular ligand-binding loop [32]. In contrast, the 2705(T/C) [rs363504] transition in exon 17 results in a non-synonymous change (L902S) that affects the intracellular C-terminal domain [25]. Alternative splicing of the primary GluK1 transcript has been reported to generate two distinct mRNA species: NM_ 000830.3 and NM _ 175611.2 [1]. Interestingly, sequence align- ments and Clustal-X analysis with the genomic contig of GluK1 (NT_ 011512.10) indicates that the NM _ 000830.3 transcript includes coding sequences from exons 9 and 17 that are absent, however, in the alternatively spliced NM_ 175611.2 transcript (sequence alignment data not shown; Fig. 1). The 2705(T/C) polymorphism in exon 17 of GluK1 is thus differentially expressed in the splice variants (Fig. 1).

We genotyped the polymorphisms by means of PCRcoupled RFLP assays and evaluated them with respect to heterozygosity, allele frequency, linkage disequilibrium, as well as the stage and parental origin of nondisjunction in DS patient families. We report that distribution of allele frequencies are in Hardy-Weinberg equilibrium and pair-wise combinations of alleles are in significant linkage disequilibrium of weak magnitude. The $1173(\mathrm{C} / \mathrm{T})$ marker exhibits moderate heterozygosity (0.339) and the non-disjoining allele originates both during meiosis-I and meiosis-II in a bi-parental mode that likely confers risk of DS-related MR. The estimated ratio of meiosis-I to meiosis-II errors is $4: 1$ in maternal cases and 2:1 in paternal cases suggesting varying risk for non-disjunction.

\section{Materials and methods}

\subsection{Bio-informatics procedures}

GluK1 genomic DNA sequence (NT_ 011512.10 gi: 51475294), alternatively spliced mRNA transcript sequences (NM_175611.2, gi: 59710095; NM _ 000830.3, gi: 59710094) and corresponding cDNA se- 
quences [15] were obtained from the NCBI database (release date: February 29, 2008). Data pertaining to single nucleotide polymorphisms in GluK1 were retrieved from dbSNP (http://www.ncbi.nlm.nih.gov/ sites/entrez? $\mathrm{db}=\mathrm{snp}$ ). The expression profile for GluK1 mRNA in human tissues was obtained from T1Dbase [23] database that uses data from Gene Novartis Foundation (GNF) database [3]. Data pertaining to murine brain region-specific expression of GluK1 was also obtained from the GNF database [3]. An Average Difference Value, calculated by the Affymetrix software, is proportional to the mRNA content in the sample and is the estimate of cross hybridization that exceeds specific signal intensity [3]. The GluK1 genomic DNA sequence (NT_011512.10) was aligned with cDNAs corresponding to two alternatively spliced transcripts (NM_175611.2 and NM_ 000830.3) using Clustal X-v.1.83 [16] under alignment parameters with pair gap penalties of 10.00 for gap opening and 0.10 for gap extension and multiple alignment penalties of 10.00 for gap opening and 0.20 for gap extension. Similar alignment of NT_011512.10 with NM_ 175611.2 and NM_ 000830.3 sequences was performed with the help of the Spidey software program [31] that defines windows on the genomic sequence and performs $\mathrm{mR}$ NA: DNA alignment separately within each window; the alignment parameter is based on minimum \% identity and mRNA length coverage which are set at default value.

\subsection{Subject ascertainment and diagnostic procedures}

We recruited 86 DS patient families (58 trios and 28 duos) and 13 singleton cases from the Out-Patient Department of Manovikas. The DS patient group comprised of 62 males and 37 females with a mean age of $(7.34 \pm 5.38)$ years. All patients fulfilled criteria for Down syndrome as per SMITH'S Recognizable patterns of human malformation [19] and the criteria for mental retardation as per Diagnostic and Statistical Manual-IV text revised version [4]. Detailed demographic and clinical history was obtained from parents and other participants by means of a structured questionnaire. Venous blood samples $(\sim 5 \mathrm{ml})$ were collected for genomic DNA analysis after securing written informed consent from all participants. For DS cases below 5 years of age $(n=46)$, the developmental delay was evaluated by means of functional assessment; in older children with DS ( $n=53)$, the degree of mental retardation was assessed by means of the Wechsler's IQ testing procedure [11]. The study protocol had pri- or approval of the Institutional Ethical Committee of Manovikas. Approximately $76.5 \%$ of all recruited individuals were native speakers of Bengali; the sample studied represents a mixture of various caste and religious affiliations: Hindu [brahmin (26.50\%), kayastha $(33.44 \%)$, baisya $(9.46 \%)$, vaidya $(0.63 \%)$, mahisya (2.84\%), scheduled caste (16.40\%)], Muslim (10.09\%) and Christian $(0.63 \%)$.

\subsection{Genotyping procedures}

The salting out procedure of Miller et al. 1988 [29] was used to isolate genomic DNA from whole blood lymphocytes. Polymerase Chain reaction (PCR)-based amplification of genomic DNA targets was carried out in the DNA Engine Thermal Cycler (MJ Research PTC-200). For the 522(A/C) polymorphism 10 pmol of each forward (5'-CATACAGACCCGCTGGAAAC$\left.3^{\prime}\right)$ and reverse (5'-TGAGTCCCATACCTGTGCTG$3^{\prime}$ ) primers were used in reactions containing $100 \mathrm{ng}$ of genomic DNA, 1-X Thermopol-II buffer composed of $10 \mathrm{mM} \mathrm{KCl}, 10 \mathrm{mM}\left(\mathrm{NH}_{4}\right)_{2} \mathrm{SO}_{4}, 20 \mathrm{mM}$ Tris- $\mathrm{HCl}$ (pH 8.8 at $25^{\circ} \mathrm{C}$ ), $0.1 \%$ Triton X-100 (New England Biolabs), $1.5 \mathrm{mM} \mathrm{MgSO}_{4}, 200 \mu \mathrm{M}$ dNTPs, 0.2 unit Taq DNA polymerase and $0.01 \%$ gelatin in a total volume of $20 \mu \mathrm{l}$. The cycling conditions were as follows: heat denaturation at $95^{\circ} \mathrm{C}$ for $10 \mathrm{~min}$ followed by 30 cycles of denaturation at $95^{\circ} \mathrm{C}$ for $30 \mathrm{sec}$, annealing at $59^{\circ} \mathrm{C}$ for $30 \mathrm{sec}$, elongation at $72^{\circ} \mathrm{C}$ for $30 \mathrm{sec}$, and a final elongation step at $72^{\circ} \mathrm{C}$ for $10 \mathrm{~min}$. After PCR amplification, restriction enzyme digestion was carried out with $200 \mathrm{ng}$ PCR product, 0.2 unit of Btg I (New England Biolabs) enzyme, 1X NEB3 assay buffer containing $100 \mathrm{mM} \mathrm{NaCl}, 50 \mathrm{mM}$ Tris- $\mathrm{HCl}$ (pH 7.9), $10 \mathrm{mM}$ $\mathrm{MgCl}_{2}, 1 \mathrm{mM}$ Dithiothreitol and $1 \mathrm{X}$ nuclease free BSA in $20 \mu \mathrm{l}$ reaction volume at $37^{\circ} \mathrm{C}$ for $16 \mathrm{~h}$. For amplification of the 2705 (T/C) polymorphism, forward $\left(5^{\prime}-\right.$ CCATCCAACCAACTCCACTT- $\left.3^{\prime}\right)$ and reverse (5'CATTTTCTACTGGGCACATC- $3^{\prime}$ ) primers were used as per reaction conditions described previously. The cycling conditions were as follows: heat denaturation at $95^{\circ} \mathrm{C}$ for $10 \mathrm{~min}$, followed by 30 cycles of denaturation at $95^{\circ} \mathrm{C}$ for $30 \mathrm{sec}$, annealing at $56^{\circ} \mathrm{C}$ for $30 \mathrm{sec}$, elongation at $72^{\circ} \mathrm{C}$ for $30 \mathrm{sec}$, and a final elongation step at $72^{\circ} \mathrm{C}$ for $10 \mathrm{~min}$. The PCR amplicon ( 200 ng) was digested with 0.2 unit Ase I (Bangalore Genei) enzyme, $1 \mathrm{X}$ assay buffer E (Bangalore Genei) containing $33 \mathrm{mM}$ Tris-acetate ( $\mathrm{pH} 7.9), 10 \mathrm{mM} \mathrm{Mg}$-acetate, $66 \mathrm{mM}$ K-acetate and $0.5 \mathrm{mM}$ dithiothreitol (Bangalore Genei) in a $20 \mu \mathrm{l}$ reaction volume at $37^{\circ} \mathrm{C}$ for $16 \mathrm{~h}$. For 1173(C/T) polymorphism, the PCR amplification was 
performed with $15 \mathrm{pmol}$ each of forward primer $\left(5^{\prime}\right.$ CAGCCACATTTCTTCTTGTCC-3') and mutagenic reverse primer $\left(5^{\prime}\right.$-CCTTCCTCTTTGAGACTAAT $\underline{-}$ AT- $\left.3^{\prime}\right)$ [14]. All the reaction and cycling conditions were same as described previously. The PCR product (500ng) was subjected to restriction enzyme digestion with 0.5 unit $E c o R V$ (Bangalore Genei) enzyme, 1Xassay buffer A (Bangalore Genei) containing $10 \mathrm{mM}$ Tris-Cl (pH 7.9), $150 \mathrm{mM} \mathrm{NaCl}, 7 \mathrm{mM} \mathrm{MgCl} 2,1 \mathrm{mM}$ dithiothreitol (Bangalore Genei) and $1 \mathrm{X}$ nuclease free BSA (Bangalore Genei) in a $20 \mu \mathrm{l}$ reaction volume at $37^{\circ}$ for $16 \mathrm{~h}$. Restriction fragments and size standards were resolved in $16 \%$ polyacrylamide gels containing $5 \%$ glycerol. Electrophoresis was carried out at $90 \mathrm{~V}$ (constant voltage) for $\sim 14$ h overnight. Size discrimination of bands was performed by means of Quantity One software (BioRad, CA).

\subsection{Statistical analysis}

Analysis of allele and genotype frequency, heterozygosity and tests for Hardy-Weinberg equilibrium (HWE) were performed using the TFPGA v1.3 software program [24]. The Likelihood Ratio test [10] was performed to ascertain HWE proportions. The EH+ program v.1.2 [18] was used to estimate the haplotype frequencies. Subsequently, we computed linkage disequilibrium values using the 2LD program v.1.00 [9] and JLIN: Java linkage disequilibrium plotter v.1.50 [21] software.

\section{Resullts}

GluK1 polymorphisms were characterized by PCRcoupled RFLP assays. Genotyping of the 522(A/C) SNP was performed with Btg I that cleaves the sequence $\mathrm{C}{ }^{\downarrow} \mathrm{CRYGG}$ but not CARYGG. Accordingly, enzymatic digestion of a $167 \mathrm{bp}$ PCR-amplicon yields retriction fragments of $132 \mathrm{bp}$ and $35 \mathrm{bp}$. The $32 \mathrm{bp}$ band was run-off to optimize resolution and, as shown in Fig. 2, the A/A genotype is identified by an uncut $167 \mathrm{bp}$ band (lane 1), the $\mathrm{A} / \mathrm{C}$ heterozygote yields two bands corresponding to $167 \mathrm{bp}$ and $132 \mathrm{bp}$ (lane 2) and the $\mathrm{C} / \mathrm{C}$ genotype is denoted by a single band of $132 \mathrm{bp}$ (lane 3). Out of 510 chromosomes analyzed, only 1 individual was identified with $\mathrm{C} / \mathrm{C}$ genotype (132 bp) (lane 3).

Genotyping of the $1173(\mathrm{C} / \mathrm{T}) \mathrm{SNP}$ was performed with $E c o R V$ that cleaves the sequence GAT ${ }^{\downarrow}$ ATC but not GACATC. Enzymatic digestion of a 121 bp PCR-

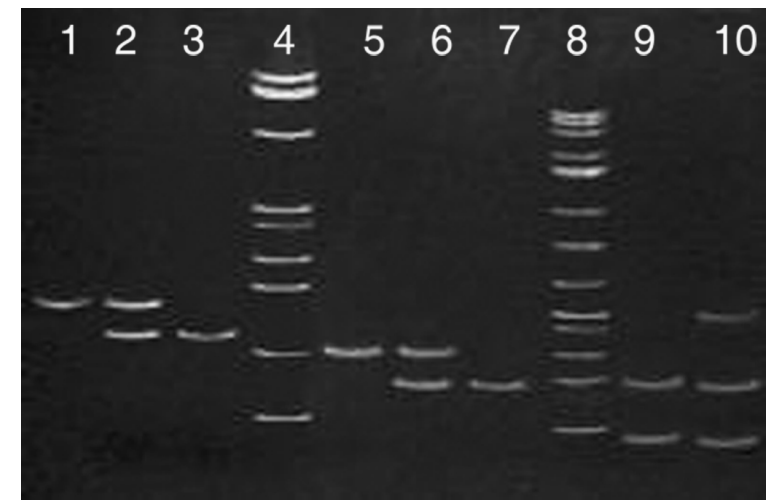

Fig. 2. Genotypes identified by PCR-coupled RFLP analyses of various polymorphic loci: 522(A/C)[lane 1: $\mathrm{A} / \mathrm{A}$, lane 2: $\mathrm{A} / \mathrm{C}$, lane 3: $\mathrm{C} / \mathrm{C}] ; 1173(\mathrm{C} / \mathrm{T})[$ lane 5: $\mathrm{C} / \mathrm{C}$, lane 6: $\mathrm{C} / \mathrm{T}$, lane $7: \mathrm{T} / \mathrm{T}]$ and 2705(T/C)[lane 9: T/T, lane 10: T/C]; lane 4: size standards obtained from $\Phi$ x174DNA digested with Hae III; lane 8: size standards obtained from $\Phi$ x174DNA digested with Hinf $I$.

amplicon yields restriction fragments of $98 \mathrm{bp}$ and $23 \mathrm{bp}$. The $23 \mathrm{bp}$ band was run-off to optimize resolution. As shown in Fig. 2, the C/C genotype is identified by an uncut 121 bp band (lane 5), C/T heterozygotes yield two bands corresponding to $121 \mathrm{bp}$ and $98 \mathrm{bp}$ (lane 6) while the T/T genotype is denoted by a $98 \mathrm{bp}$ band (lane 7).

Genotyping of the 2705(T/C) SNP was performed using Ase $I$ that cleaves $\mathrm{A}^{\downarrow}$ TTAAT but not ACTAAT. Enzymatic cleavage of a 153 bp PCR-amplicon yields restriction fragments of $96 \mathrm{bp}$ and $57 \mathrm{bp}$. As shown in Fig. 2, the T/T genotype is identified by bands of $96 \mathrm{bp}$ and 57 bp (lane 9), the heterozygous T/C genotype is denoted by three bands of $153 \mathrm{bp}, 96 \mathrm{bp}$ and $57 \mathrm{bp}$ (lane 10) and the $\mathrm{C} / \mathrm{C}$ genotype corresponds to the uncut band of $153 \mathrm{bp}$.

The distributions of allele and genotype frequencies for all three loci under study are shown in Table 1. Of the three polymorphisms studied, the $1173(\mathrm{C} / \mathrm{T})$ marker is the most informative due to moderate heterozygosity (0.339) (Table 1). For the 522(A/C) and 2705(T/C) polymorphisms, we determined that the $\mathrm{C}$ allele is the minor allele as indicated by allele frequencies of 0.086 and 0.078 , respectively (Table 1). Not surprisingly, the rare allele is commonly manifested in the heterozygote in case of both polymorphisms. In our sample, we detected only one individual who was homozygous for $522(\mathrm{C} / \mathrm{C})$ and none with the $2705(\mathrm{C} / \mathrm{C})$ genotype (Table 1) and that may be the reason why distribution of allele frequencies at the 2705 (T/C) locus is only marginally in Hardy-Weinberg equilibrium $(p=0.065$ at C.I. $=95 \%$; Table 1). Overall, there is no significant deviation in allele frequencies from that expected ac- 
Table 1

Determination of Hardy-Weinberg equilibrium proportions

\begin{tabular}{|c|c|c|c|c|c|c|c|c|}
\hline $\mathrm{N}$ & Polymorphism & Allele & Frequency & Genotype & Frequency & $\begin{array}{c}\text { Heterozygosity } \\
\text { (unbiased) }\end{array}$ & $\mathrm{G}$ & $P$ \\
\hline 255 & $522(\mathrm{~A} / \mathrm{C})$ & $\begin{array}{l}\text { A-522 } \\
\text { C-522 }\end{array}$ & $\begin{array}{l}0.914 \\
0.086\end{array}$ & $\begin{array}{l}\mathrm{AA} \\
\mathrm{AC} \\
\mathrm{CC}\end{array}$ & $\begin{array}{l}0.831(212) \\
0.168(42) \\
0.004(01)\end{array}$ & 0.158 & 0.597 & 0.44 \\
\hline 255 & $1173(\mathrm{C} / \mathrm{T})$ & $\begin{array}{l}\mathrm{C}-1173 \\
\mathrm{~T}-1173\end{array}$ & $\begin{array}{l}0.784 \\
0.216\end{array}$ & $\begin{array}{l}\text { CC } \\
\text { CT } \\
\text { TT }\end{array}$ & $\begin{array}{l}0.600(153) \\
0.369(94) \\
0.031(08)\end{array}$ & 0.339 & 2.190 & 0.14 \\
\hline 255 & 2705(T/C) & $\begin{array}{r}\mathrm{T}-2705 \\
\mathrm{C}-2705\end{array}$ & $\begin{array}{l}0.922 \\
0.078\end{array}$ & $\begin{array}{l}\text { TT } \\
\text { TC } \\
\text { CC }\end{array}$ & $\begin{array}{l}0.843(215) \\
0.157(40) \\
0.000(00)\end{array}$ & 0.145 & 3.408 & 0.07 \\
\hline
\end{tabular}

Figures in parentheses and under column $\mathrm{N}$ denote number of individuals; $\mathrm{G}$ ( $\log _{0}$ of likelihood ratio), and $P$ (probability) values derived at $95 \%$ C.I. using the maximum likelihood ratio test of HWE (10); data pertain to analysis of 255 control samples.

Table 2

Pair-wise values of raw (D) and normalized $\left(D^{\prime}\right)$ linkage disequilibrium coefficients for allelic combinations of human kainate receptor $[522(\mathrm{~A} / \mathrm{C}), 1173(\mathrm{C} / \mathrm{T})$ and $2705(\mathrm{~T} / \mathrm{C})]$ polymorphisms in 255 controls

\begin{tabular}{cllrrrl}
\hline $\mathrm{N}$ & Haplotype & Frequency & \multicolumn{1}{c}{$\mathrm{D}$} & \multicolumn{1}{c}{$\mathrm{D}^{\prime}$} & $\chi^{2}(d f=1)$ & $\begin{array}{l}\text { Significance } \\
P(D=0)\end{array}$ \\
\hline 255 & A-522-C-1173 & 0.75 & 0.029 & 0.422 & 31.18 & 0.0001 \\
& A-522-T-1173 & 0.17 & -0.029 & -0.422 & & \\
& C-522-C-1173 & 0.04 & -0.029 & -0.422 & & \\
& C-522-T-1173 255 & 0.05 & 0.029 & 0.422 & & \\
& C-1173-T-2705 & 0.74 & 0.021 & 0.340 & 18.30 & 0.0001 \\
& C-1173-C-2705 & 0.04 & -0.021 & -0.340 & & \\
& T-1173-T-2705 & 0.18 & -0.021 & -0.340 & & \\
& T-1173-C-2705 & 0.04 & 0.021 & 0.340 & & \\
A-522-T-2705 & 0.84 & 0.003 & 0.037 & 0.62 & 0.43 \\
& A-522-C-2705 & 0.07 & -0.003 & -0.037 & & \\
& C-522-T-2705 & 0.08 & -0.003 & -0.037 & & \\
& C-522-C-2705 & 0.009 & 0.003 & 0.037 & & \\
\hline
\end{tabular}

cording to HWE proportions. The marker loci are not subject to evolutionary forces and the identified alleles are segregating stably in the sample population. Furthermore, parental transmission of these alleles may be conveniently studied in a family-based study design.

We next estimated linkage disequilibrium (LD) values between pair-wise combinations of alleles comprising the $522(\mathrm{~A} / \mathrm{C}), 1173(\mathrm{C} / \mathrm{T})$ and $2705(\mathrm{~T} / \mathrm{C})$ polymorphic systems by using data from control samples. By computing the normalized disequilibrium coefficient $\left(\mathrm{D}^{\prime}\right)$, we determined that significant $\left(\chi^{2}=31.18, d f=\right.$ $1, p=0.0001)$ LD of weak magnitude $\left(D^{\prime}=0.422\right.$; $\left.r^{2}=0.061\right)$ exists between $522(\mathrm{~A} / \mathrm{C})-1173(\mathrm{C} / \mathrm{T})$, the rank order of estimated haplotype frequencies being A522-C1173 > A522-T1173 > C522-T1173 > C522C1173 (Table 2). The very low value for the latter twohaplotype combinations is due to the low frequencies of the C522 and T1173 minor alleles (Table 1). Similarly, $1173(\mathrm{C} / \mathrm{T})-2705(\mathrm{~T} / \mathrm{C})$ markers are also in significant LD $\left(\chi^{2}=18.30, d f=1, p=0.0001\right) \mathrm{LD}$, albeit of lower magnitude $\left(D^{\prime}=0.340 ; r^{2}=0.036\right)$. A positive
$\mathrm{D}^{\prime}$ value and the magnitude of estimated haplotype frequencies indicates that A522-C1173 and C1173-T2705 haplotypes tend to segregate on the same chromosome more often than expected by mere chance (Table 2). Of 255 individuals in the total sample, we detected only 1 individual who was homozygous for the rare C522 allele (Table 1) and none with the 2705(C/C) genotype. Not surprisingly, the estimated C522-C2705 haplotype frequency is negligible (0.009) (Table 2) and no LD exists between these markers.

From a total sample of 58 trios, we excluded 25 trios as being non-informative with respect to the $1173(\mathrm{C} / \mathrm{T})$ marker polymorphism since their genotypes were either all homozygous (lanes 1, 2, 3) or heterozygous (lanes 5, $6,7)$ (Fig. 3A). A total of 4 trios showed parental genotypes that were heterozygous (lanes 9 and 10) while corresponding offspring genotypes were homozygous for either the C-1173 allele (lane 11) or for the T-1173 allele (lane 12) (Fig. 3A). We infer that either parent in these trios could have contributed the non-disjoining allele (C or T) during meiosis-II (Table 3a). 
Table $3 \mathrm{a}$

Determination of parent/stage of origin of non-disjunction error in trio/duo families genotyped for $1173(\mathrm{C} / \mathrm{T})$ polymorphism

\begin{tabular}{|c|c|c|c|c|c|}
\hline $\begin{array}{c}\text { NDJP } \\
\text { genotype }\end{array}$ & $\begin{array}{c}\text { CDJP } \\
\text { genotype }\end{array}$ & $\begin{array}{c}\text { child } \\
\text { genotype }\end{array}$ & $\begin{array}{c}\text { marker } \\
\text { status }\end{array}$ & stage of origin & $\begin{array}{l}\text { trios }(\mathrm{T}) \\
/ \text { duos }(\mathrm{D})\end{array}$ \\
\hline CT $($ ( / / $)$ & $\mathrm{CT}\left(\delta^{1 / 9}\right)$ & $\mathrm{CCC}$ & $\mathrm{R}$ & M-II & $3(\mathrm{~T})$ \\
\hline CT $(+/ /)$ & $\mathrm{CT}(\delta / 9)$ & TTT & $\mathrm{R}$ & M-II & $1(\mathrm{~T})$ \\
\hline $\mathrm{CC}($ (†) & $\mathrm{CT}(\lesssim)$ & $\mathrm{CCC}$ & $\mathrm{N}$ & M-I & $10(\mathrm{~T})$ \\
\hline $\mathrm{CC}\left({ }^{2}\right)$ & CT (P) & $\mathrm{CCC}$ & $\mathrm{N}$ & M-I & $4(\mathrm{~T})$ \\
\hline $\mathrm{CT}(\delta)$ & CC (웅 & ССТ/СТT & $\mathrm{N} / \mathrm{R}$ & M-I/M-II & $4(\mathrm{~T})$ \\
\hline CT (o) & $\mathrm{CC}($ ( ) & ССТ/СТT & $\mathrm{N} / \mathrm{R}$ & M-I/M-II & $8(\mathrm{~T})$ \\
\hline $\mathrm{CT}($ (⿱中一) $)$ & TT (ठ) & ССТ/CTT & $\mathrm{R} / \mathrm{N}$ & M-II/M-I & $3(\mathrm{~T})$ \\
\hline missing ( & CT (9) & $\mathrm{CCC}$ & $\mathrm{N}$ & M-I & 2 (D) \\
\hline missing (ठ) & CT (q) & TTT & $\mathrm{N}$ & M-I & 1 (D) \\
\hline missing () & $\mathrm{CT}(8)$ & $\mathrm{CCC}$ & $\mathrm{N}$ & M-I & 2 (D) \\
\hline missing (ठ) & CC (ㅇ) & ССТ/СТT & N/R & M-I/M-II & 4 (D) \\
\hline missing ( & TT (q) & ССТ/CTT & $\mathrm{R} / \mathrm{N}$ & M-II/M-I & 1 (D) \\
\hline
\end{tabular}

Of the remaining 29 informative trios, analyses of parental genotypes revealed that 14 trios comprised of one parent heterozygous for the $1173(\mathrm{C} / \mathrm{T})$ marker, whereas, the other parent and the proband were homozygous. In such families, the heterozygous parent was the assumed to be the informative or correctly disjoining parent (CDJP) while the other parent was deemed to be the non-disjoining parent (NDJP) in whom the error occurred in meiosis I. As shown in Table $3 \mathrm{a}$ and Fig. 3B, non-disjunction occurred during maternal meiosis I (lane 1, 2, 3) in 10 out of 14 such trios while the error occurred in paternal meiosis I (lane 5, 6, 7) in 4 trios.

Analysis of the remaining 15 trios reveals that one parent and the proband are both heterozygous for $1173(\mathrm{C} / \mathrm{T})$. In such families, the homozygous parent is deemed informative (CDJP) as the offspring/proband genotype is recombinant; the heterozygous parent is therefore the NDJP. Although the parent-of-origin with respect to the non-disjoining allele can be readily verified in such families, determining the stage at which the error occurred remains equivocal due to inherent limitations of RFLP-based genotyping of trisomic individuals. As shown in Fig. 3C, the error can occur either during paternal meiosis I or II if the proband genotype is CCT or CTT, as observed in 4 out of 15 trios (lanes 1 , $2,3)$. Similarly, the error may occur either in maternal meiosis I or during maternal meiosis II, given that offspring genotype is CCT or CTT in 8 out of 15 families (lane $5,6,7$ ). In the preceding 12 trios, the informative parent had the $\mathrm{C} / \mathrm{C}$ genotype. Interestingly, the rare allele also manifests as the informative T/T genotype in 3 out of 15 trios and the error could correspondingly occur in maternal meiosis II or I as offspring genotypes are CCT or CTT (lanes 9, 10, 11)(Table 3a).
From a total sample of 28 duos we excluded 18 pairs since the genotypes were either all homozygous or heterozygous for the $1173(\mathrm{C} / \mathrm{T})$ marker. We observed that 10 duos possessed offspring genotypes that were recombinant with respect to the available parental genotype and were deemed informative as the CDJP was identified (Fig. 3D) and the missing parental genotype corresponds to the NDJP. However, determining the stage at which the non-disjoining allele originates remains equivocal (Table 3a). Taken together, results indicate that $\mathrm{C}-1173$ is the non-disjoining allele in 22 cases, a total of 12 cases originating in maternal meiosisI, 7 cases in paternal meiosis-I and 3 cases in which the error is likely at the level of meiosis-II with unknown parent-of-origin. An error in meiosis-II accounts for non-disjunction of the rare T-1173 allele in single case, the parent-of-origin being unresolved. The non-disjoining allele was not ascertained in 20 cases i.e., in 13 cases of maternal origin and 7 cases of paternal origin. When we analyzed the genotypes of 13 DS singletons and found them to be CCC we inferred that the $\mathrm{C}-1173$ allele is the non-disjoining allele in all these cases. This is in agreement with our finding that the major allele frequency for $\mathrm{C}-1173$ is $\sim 0.78$ (Table 1). The estimated ratio of meiosis-I to meiosis-II errors arising from allelic non-disjunction of $1173(\mathrm{C} / \mathrm{T})$ is $4: 1$ in maternal cases and 2:1 in paternal cases (Table $3 \mathrm{a}$ ).

With respect to $522(\mathrm{~A} / \mathrm{C}), 42$ trios were excluded from a total sample of 58 trios, as they are noninformative. As shown in Table 3b, non-disjunction originated in the mother for 10 trios and in the father for 5 trios. However, the parent-of-origin could not be ascertained in the case of 1 trio. The stage of nondisjunction was attributable to meiosis-I in 9 trios and 


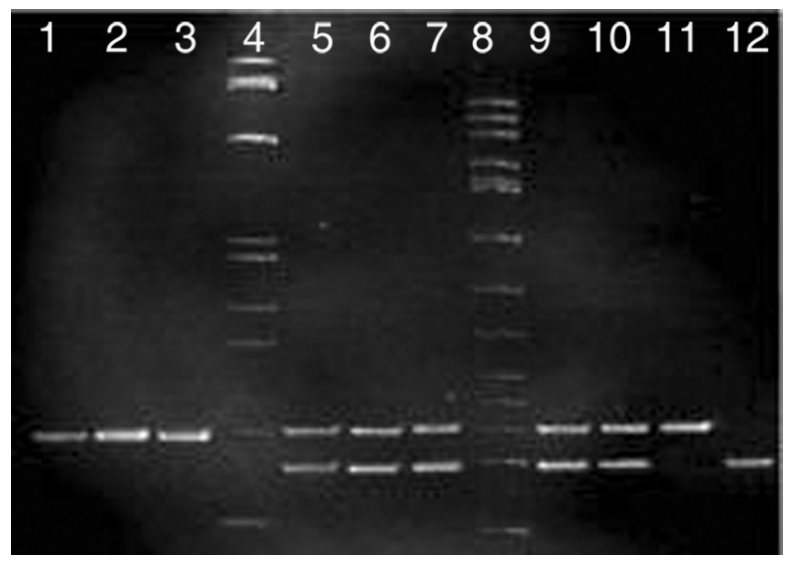

(a)

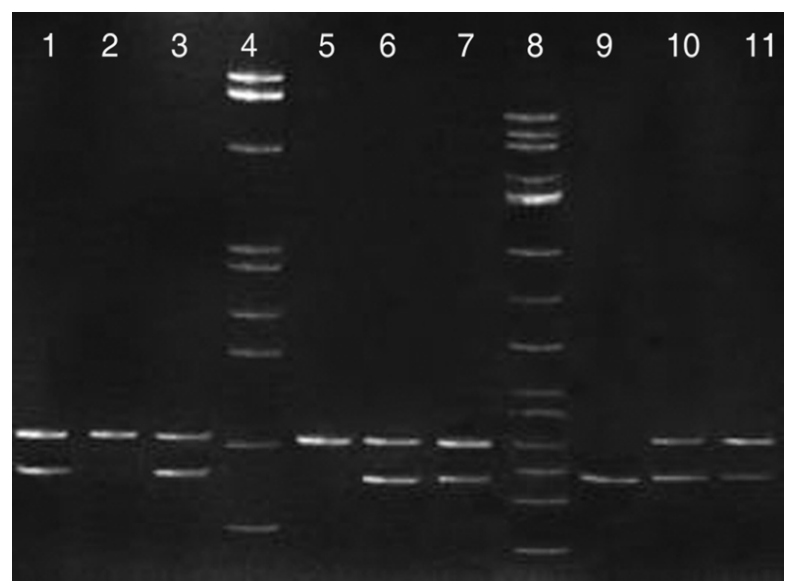

(c)

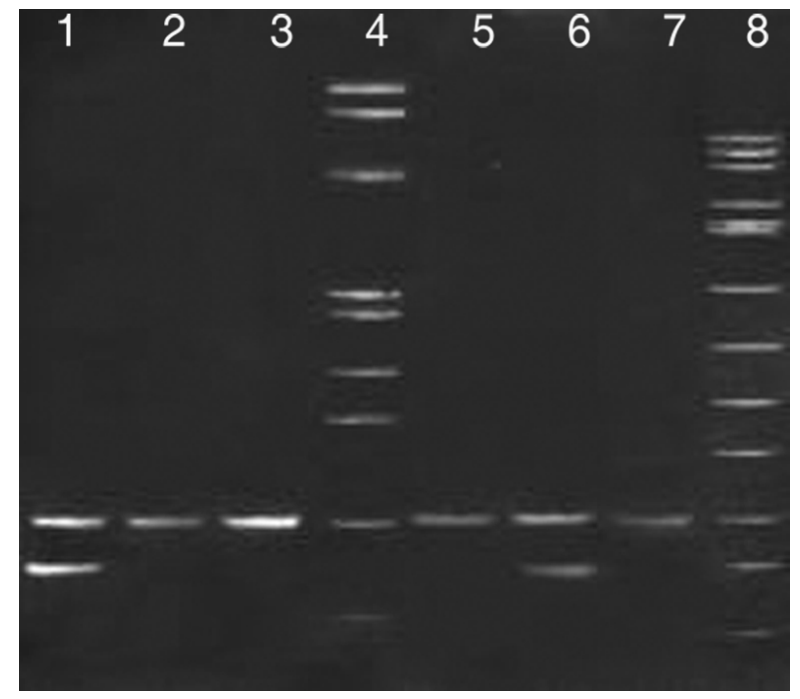

(b)

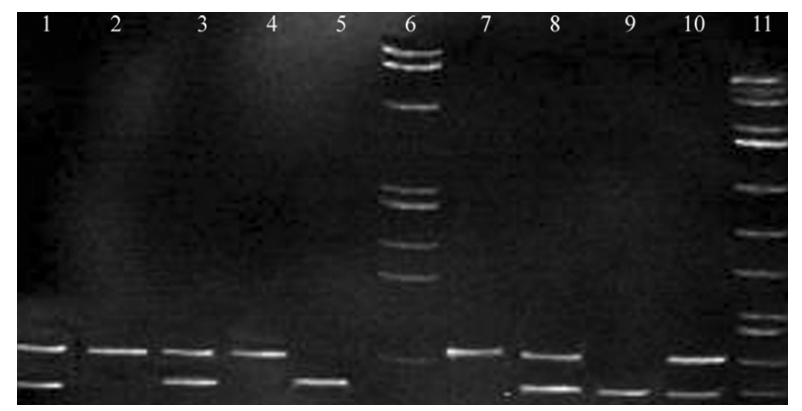

(d)

Fig. 3. A: Indicates trio patient family genotyped for $1173(\mathrm{C} / \mathrm{T})$ polymorphism: lane $1: 8: C / C$, lane 2 : $q \mathrm{C} / \mathrm{C}$, lane 3 : proband $\mathrm{C} / \mathrm{C} / \mathrm{C}$, lane 4 : size standards obtained from $\Phi$ x174DNA digested with Hae III, lane 5: $\lambda \mathrm{C} / \mathrm{T}$, lane 6: $\rho \mathrm{C} / \mathrm{T}$, lane 7: proband C/C/T or C/T/T, lane 8: size standards obtained from $\Phi$ x174DNA digested with $\operatorname{Hinf} I$, lane 9: $7 \mathrm{C} / \mathrm{T}$, lane 10: \& C/T, lane 11: proband C/C/C, lane 12: proband T/T/T. B: Indicates trio patient family genotyped for $1173(\mathrm{C} / \mathrm{T})$ polymorphism: lane 1 : father $\mathrm{C} / \mathrm{T}$, lane 2 : mother $\mathrm{C} / \mathrm{C}$, lane 3 : $\mathrm{C} / \mathrm{C} / \mathrm{C}$, lane 4 : size standards obtained from $\Phi$ x174DNA digested with Hae III, lane 5: father C/C, lane 6: mother C/T, lane 7: proband C/C/C, lane 8: size standards obtained from $\Phi$ x174DNA digested with Hinf I. C: Indicates trio patient family genotyped for 1173(C/T) polymorphism: lane 1: father C/T, lane 2: mother C/C, lane 3: proband $\mathrm{C} / \mathrm{C} / \mathrm{T}$, lane 4: size standards obtained from $\Phi$ x174DNA digested with Hae III, lane 5: father $\mathrm{C} / \mathrm{C}$, lane 6: mother C/T, lane 7: $\mathrm{C} / \mathrm{C} / \mathrm{T}$ or $\mathrm{C} / \mathrm{T} / \mathrm{T}$, lane 8: size standards obtained from $\Phi$ x174DNA digested with Hinf I, lane 9: father T/T, lane 10: mother C/T, lane 11:proband $\mathrm{C} / \mathrm{C} / \mathrm{T}$ or $\mathrm{C} / \mathrm{T} / \mathrm{T}$. D: Indicates duo family genotyped for $1173(\mathrm{C} / \mathrm{T})$ polymorphism: lane 1 : father $\mathrm{C} / \mathrm{T}$, lane 2: proband $\mathrm{C} / \mathrm{C} / \mathrm{C}$, lane 3 : mother $\mathrm{C} / \mathrm{T}$, lane 4: proband $\mathrm{C} / \mathrm{C} / \mathrm{C}$, lane 5: proband T/T/T, lane 6: size standards obtained from $\Phi$ x174DNA digested with Hinf I, lane 7: mother C/C, lane 8: $\mathrm{C} / \mathrm{C} / \mathrm{T}$ or $\mathrm{C} / \mathrm{T} / \mathrm{T}$, lane 9: mother $\mathrm{T} / \mathrm{T}$, lane 10: proband $\mathrm{C} / \mathrm{C} / \mathrm{T}$ or $\mathrm{C} / \mathrm{T} / \mathrm{T}$, lane 11: size standards obtained from $\Phi$ x174DNA digested with Hinf I.

meiosis-II in 1 trio whereas it could not be ascertained in 6 trios (Table 3b). We observed that 4 duos (Table $3 b$ ) possessed offspring genotypes that were recombinant with respect to the available parental genotype (CDJP) and the NDJP was inferred. Accordingly, nondisjunction occurred in meiosis-I in a single trio while parental origin could not be determined in 3 trios. The A-522 allele was identified as the non-disjoining allele in 14 cases, a total of 9 cases originating in maternal
meiosis-I, 4 cases in paternal meiosis-I and 1 case in meiosis-II with equivocal parent-of-origin. Although the PCR-RFLP technique did not permit identification of the non-disjoining allele in 6 families, the parent-oforigin in 5 cases is the mother and in 1 case corresponds to the father. We analyzed the genotypes of 13 DS singletons and found them to be all AAA. Accordingly, we infer that the A-522 allele is the non-disjoining allele in all these cases. 
Table $3 b$

Determination of parent/stage of origin of non-disjunction error in trio/duo families genotyped for 522(A/C) polymorphism

\begin{tabular}{|c|c|c|c|c|c|}
\hline $\begin{array}{l}\text { NDJP } \\
\text { genotype }\end{array}$ & $\begin{array}{c}\text { CDJP } \\
\text { genotype }\end{array}$ & $\begin{array}{l}\text { child } \\
\text { genotype }\end{array}$ & $\begin{array}{c}\text { marker } \\
\text { status }\end{array}$ & stage of origin & $\begin{array}{l}\# \text { trios }(\mathrm{T}) \\
/ \text { duos }(\mathrm{D})\end{array}$ \\
\hline $\mathrm{AC}(\phi / \delta)$ & $\mathrm{AC}(\delta / 9)$ & AAA & $\mathrm{R}$ & M-II & $1(\mathrm{~T})$ \\
\hline AA (P) & $\mathrm{AC}(3)$ & AAA & $\mathrm{N}$ & M-I & $5(\mathrm{~T})$ \\
\hline AA $\left(\delta^{2}\right)$ & $\mathrm{AC}(\mathrm{q})$ & AAA & $\mathrm{N}$ & M-I & $4(\mathrm{~T})$ \\
\hline $\mathrm{AC}\left(\zeta^{\lambda}\right)$ & AA (O) & AAC/ACC & $\mathrm{N} / \mathrm{R}$ & M-I/M-II & $1(\mathrm{~T})$ \\
\hline $\mathrm{AC}(\phi)$ & AA ( & AAC/ACC & N/R & M-I/M-II & $5(\mathrm{~T})$ \\
\hline missing (†) & $\mathrm{AC}(\mathrm{\delta})$ & AAA & $\mathrm{N}$ & M-I & 1 (D) \\
\hline missing $\left({ }^{\prime}\right)$ & AA (O) & AAC/ACC & $\mathrm{N} / \mathrm{R}$ & M-I/M-II & 2 (D) \\
\hline missing (Q) & AA (ふ) & AAC/ACC & N/R & M-I/M-II & 1 (D) \\
\hline
\end{tabular}

$R=$ marker status reduced to homozygosity, $N=$ marker status not-reduced to homozygosity, $\mathrm{M}-\mathrm{I}=$ meiosis-I, M-II = meiosis-II.

Table 3c

Determination of parent/stage of origin of non-disjunction error in trio/duo families genotyped for 2705(T/C) polymorphism

\begin{tabular}{|c|c|c|c|c|c|}
\hline $\begin{array}{c}\text { NDJP } \\
\text { genotype }\end{array}$ & $\begin{array}{c}\text { CDJP } \\
\text { genotype }\end{array}$ & $\begin{array}{l}\text { child } \\
\text { genotype }\end{array}$ & $\begin{array}{c}\text { marker } \\
\text { status }\end{array}$ & stage of origin & $\begin{array}{l}\# \text { trios }(\mathrm{T}) \\
/ \text { duos }(\mathrm{D})\end{array}$ \\
\hline TT (우) & $\mathrm{TC}($ ภ) & TTT & $\mathrm{N}$ & M-I & $2(\mathrm{~T})$ \\
\hline $\mathrm{TT}(\precsim)$ & $\mathrm{TC}(+)$ & TTT & $\mathrm{N}$ & M-I & $3(\mathrm{~T})$ \\
\hline $\mathrm{TC}(\precsim)$ & TT (웅 & TTC/TCC & N/R & M-I/M-II & $4(\mathrm{~T})$ \\
\hline $\mathrm{TC}($ (ㅇ) & TT (ふ) & TTC/TCC & $\mathrm{N} / \mathrm{R}$ & M-I/M-II & $2(\mathrm{~T})$ \\
\hline missing $(q)$ & $\mathrm{TC}(\precsim)$ & TTT & $\mathrm{N}$ & M-I & 1 (D) \\
\hline missing $(ð)$ & TC (우) & TTT & $\mathrm{N}$ & M-I & 2 (D) \\
\hline missing $(\gtrsim)$ & TT () & TTC/TCC & $\mathrm{N} / \mathrm{R}$ & M-I/M-II & 3 (D) \\
\hline missing $(9)$ & TT (ð) & TTC/TCC & $\mathrm{N} / \mathrm{R}$ & M-I/M-II & 2 (D) \\
\hline
\end{tabular}

$R=$ marker status reduced to homozygosity, $N=$ marker status not-reduced to homozygosity, M-I = meiosis-I, M-II = meiosis-II

From a total of 58 trios, 47 trios where excluded as being non-informative with respect to the 2705 (T/C) marker. As shown in Table 3c, non-disjunction originates in the mother for 4 trios and in the father for 7 trios. The stage of non-disjunction was attributable to meiosis-I in 5 trios and remained equivocal in 6 trios (Table 3c). We observed that 8 duos possessed offspring genotypes that were recombinant with respect to the available parental genotype (CDJP) and the NDJP was thus inferred. Accordingly, in 3 duos, the non-disjunction error occurred in meiosis-I, whereas the parent of origin remained equivocal in the remaining 5 duos. Results show that T-2705 is the nondisjoining allele in 8 cases, with 3 cases arising in maternal meiosis-I and 5 other cases arising in paternal meiosis-I (Table 3c). Though the PCR-RFLP assay did not permit identification of non-disjoining allele in 11 families, maternal non-disjunction was identified in 4 cases and with 7 cases being paternal in origin (Table 3c).

We found one trio in which the non-disjoining allele, the parent and stage-of-origin of non-disjunction could be ascertained unequivocally for all three $[522(\mathrm{~A} / \mathrm{C}), 1173(\mathrm{C} / \mathrm{T})$ and $2705(\mathrm{~T} / \mathrm{C})]$ markers. The non-disjoining alleles were independently identified as A-522, C-1173 and T-2705, respectively. Nondisjunction during maternal meiosis-I accounts for the observed genotype of this DS patient. Data from this family thus furnishes indirect evidence of triplication of the GluK1 gene in the patient since A522-C1173T2705 alleles are predicted to lie on the same chromosome (Table 2).

\section{Discussion}

This study presents evidence for allelic non-disjunction at $1173(\mathrm{C} / \mathrm{T})$ in the GluK1 gene that is an important candidate for genetic studies on DS-related MR. Moderate heterozygosity (0.339) and a major allele frequency of 0.78 renders the $1173(\mathrm{C} / \mathrm{T})$ polymorphism informative (Table 1) and the estimated proportion of meiosis-I to meiosis-II errors in the sample is $4: 1$ in maternal cases, whereas, in paternal cases the ratio is 2:1 (Table 3a). Therefore, we infer that varying risk for allelic non-disjunction derives from cellular environment during chromosome segregation. Despite lower heterozygosity values estimated for the other polymor- 
phisms studied (Table 1), we report that the distribution of allele frequencies is in Hardy-Weinberg equilibrium and that the 522(A/C)-1173(C/T) and 1173(C/T)2705(T/C) polymorphic systems are in significant linkage disequilibrium of weak magnitude (Table 2).

For the $1173(\mathrm{C} / \mathrm{T})$ polymorphism, the estimated major allele (C-1173) frequency (Table 1) is similar to reports from German (0.82) [8] but different from Japanese (0.65) populations [14]. Furthermore, the C522 and C-2705 alleles are rare in our sample (Table 1). Though the estimated frequencies for A522-C1173 and C1173-T2705 haplotypes are similar in magnitude (Table 2), the low $\mathrm{D}^{\prime}$ and $\mathrm{r}^{2}$ values are indicative of weak linkage disequilibrium (Table 2). No LD exists between the 522(A/C) and 2705(T/C) markers (Table 2) that are $\sim 136 \mathrm{~kb}$ apart and it is likely that LD erodes as a function of distance between markers [22] and/or due to their position in the medial portion of the meiotic recombination map [5,33]. Accordingly, it precludes the prediction of a robust risk haplotype although our sample included one informative trio in which the nondisjoining alleles were independently identified as A522, C-1173 and T-2705, respectively. Further studies with additional genetic markers and more patient families are warranted to substantiate the present findings.

\section{Acknowledgements}

The study was financially supported by the Department of Science and Technology (Science and Engineering Research Council) (SERC-DST), Government of India vide grant no. SR/SO/HS-59/2003 awarded to Krishnadas Nandagopal. We acknowledge all the patient families and volunteers for their participation in our study.

\section{References}

[1] A. Barbon and S. Barlati, Genomic organization, proposed alternative splicing mechanisms, and RNA editing structure of GRIK1, Cytogenetics and Cell Genetics 88 (2000), 236-239.

[2] A. Herb, M. Higuchi, R. Sprengel and P.H. Seeburg, Q/R site editing in kainite receptor GluR5 and GluR6 pre-mRNAs requires distant intronic sequences, Proceeding of the National Academy of Sciences of the United States of America $\mathbf{9 3}$ (1996), 1875-1880.

[3] A.I. Su, M.P. Cooke, K.A. Ching, Y. Hakak, J.R. Walker, T. Wiltshire, A.P. Oath, R.G. Vega, L.M. Sapnioso, A. Moqrich, A. Patapoutian, G.M. Hampton, P.G. Schultz and J.B. Hognesch, Large-scale analysis of the human and mouse transcriptomes, Proceeding of the National Academy of Sciences of the United States of America 99 (2002), 4465-4470.
[4] American Psychiatric Association, Diagnostic and Statistical Manual of Mental Disorders, (4th edition), Text Revised (DSM-IV TR 2000) version, American Psychiatric Association Press, Washington DC, 2000, pp. 39-46.

[5] A.R. Savage, M.B. Petersen, D. Pettay, L. Taft, K. Allran, S.B. Freeman, G. Karadima, D. Avramopoulos, C. Torfs, M. Mikkelsen, T.J. Hassold and S.L. Sherman, Elucidating the mechanisms of paternal non-disjunction of chromosome 21 in humans, Human Molecular Genetics 7 (1998), 1221-1227.

[6] B. Bettler and C. Mulle, Review: Neurotransmitter receptors II AMPA and kainate receptors, Neuropsychopharmacology 34 (1995), 123-139.

[7] B. Bettler, J. Boulter, I. Hermans-Borgmeyer, A. O'SheaGreenfield, E.S. Deneris, C. Mall, U. Borgmeyer, M. Hollmann and S. Heinemann, Cloning of a Novel Glutamate Receptor Subunit, GluR5: Expression in the Nervous System during development, Neuron 5 (1990), 583-595.

[8] C. Izzi, A. Barbon, R. Kretz, T. Sander and S. Barlati, Sequencing of the GRIK1 gene in patients with Juvenile Absence Epilepsy does not reveal mutations affecting receptor structure, American Journal of Medical Genetics (part-B) 114 (2002), 354-359.

[9] C. Zapata, C. Carollo and S. Rodriguez, Sampling variance and distribution of the $\mathrm{D}^{\prime}$ measure of the overall gametic disequilibrium between multiallelic loci, Annals of Human Genetics 65 (2001), 395-406.

[10] D.A. Williams, Improved likelihood ratio tests for complete contingency tables, Biometrica 63 (1976), 33-37.

[11] D. Wechsler, Wechsler Intelligence Scale for Children, (4th Edition), TX: The Psychological Corporation, San Antonio, 2003, p. 1-6.

[12] D. Patterson and A.C.S. Costa, Down syndrome and geneticsa case of linked histories, Nature Reviews Genetics 6 (2005), 137-147.

[13] D.E. Jane, D. Lodge and G.L. Collingridge, Kainate receptors: pharmacology, function and therapeutic potential, Neuropharmacology 56 (2008), 90-113.

[14] H. Shibata, A. Joo, Y. Fujii, A. Tani, C. Makino, N. Hirata, R. Kikuta, H. Ninomiya, N. Tashiro and Y. Fukumaki, Association study of polymorphisms in the GluR5 kainate receptor gene (GRIK1) with schizophrenia, Psychiatric Genetics 11 (2001), 139-144.

[15] International Human Genome Sequencing Consortium, Finishing the euchromatic sequence of the human genome, Nature 431 (2004), 931-945.

[16] J.D. Thompson, T.J. Gibson, F. Plewniak, F. Jeanmougin and D.G. Higgins, The CLUSTAL_X windows interface: flexible strategies for multiple sequence alignment aided by quality analysis tools, Nucleic Acids Research 25 (1997), 4876-4882.

[17] J.R. Korenberg, X.N. Chen, C.R. Schipper, Z. Sun, S.R. Gonsky, S. Gerwehr, N. Carpenter, C. Daumer, P. Dignan, C. Disteche, J.R.Jr. Graham, L. Hugdins, B. McGillivray, K. Miyazaki, N. Ogasawara, J.P. Park, R. Pagon, S. Pueschel, G. Sack, B. Say, S. Schuffenhauer, S. Soukup and T. Yamanaka, Down syndrome phenotypes: The consequences of chromosomal imbalance, Proceeding of the National Academy of Sciences of the United States of America 91 (1994), 4997-5001.

[18] J.H. Zhao, D. Curtis and P.C. Sham, Model free analysis and permutation tests for allelic association, Human Heredity $\mathbf{5 0}$ (2000), 133-139.

[19] K.L. Jones, Smith's recognizable patterns of Human malformation, (6th Edition), Elsevier, Philadelphia, 2006, pp. 7-12.

[20] K.F. Kerstann, E. Feingold, S.B. Freeman, L.J.H. Bean, R. Pyatt, S. Tink, A.H. Jewel, G. Capone and S.L. Sherman, Linkage 
disequilibrium mapping in trisomic populations: analytical approaches and an application to congenital heart defects in Down syndrome, Genetic Epidemiology 27 (2004), 240-251.

[21] K.W. Carter, P.A. McCaskie and L.J. Palmer, JLIN: A Java based linkage disequilibrium plotter, BMC Bioinformatics 7 (2006), 60

[22] K.G. Ardlie, L. Kruglyak and M. Seielstad, Patterns of linkage disequilibrium in the human genome, Nature Reviews Genetics 3(4) (2002), 299-309.

[23] L.J. Smink, E.M. Helton1, B.C. Healy, C.C. Cavnor1, A.C. Lam, D. Flamez, O.S. Burren, Y. Wang1, G.E. Dolman, D.B. Burdick, V.H. Everett, G. Glusman1, D. Laneri, L. Rowen1, H. Schuilenburg, N.M. Walker, J. Mychaleckyj, L.S. Wicker, D.L. Eizirik, J.A. Todd and N. Goodman1, T1DBase, a community web-based resource for type 1 diabetes research,Nucleic Acids Research 33 (2005), D544-D549.

[24] M.P. Miller, Tools for population genetic analysis (TFPGA 1.3): A window programme for the analysis of allozyme and molecular population genetic data. available online at www.marksgeneticsoftware.net/tfpga.html, 1997.

[25] N. Patil, N. Nouri, L. McAllister, H. Matsukaki and T. Ryder, Single-nuceotide polymorphism genotyping using microarrays, Current Protocols in Human Genetics (2001), Chp 2: Unit 2.9.

[26] R.H. Lipsky and D. Goldman, Genomics and variation of ionotropic glutamate receptors, Annals of the New York Academy of Sciences 1003 (2003), 22-35.

[27] S.E. Antonarakis, L. Robert, E.T. Dermitzakis, A. Reymond and S. Deutsch, Chromosome 21 and Down syndrome: from genomics to pathophysiology, Nature Reviews Genetics 5 (2004), 725-738

[28] S. Bahn, B. Volk and W. Wisden, Kainate receptor gene expression in the developing rat brain, The Journal of Neuroscience 19 (1994), 5525-5547.

[29] S.A. Miller, D.A. Dykes and H.F. Polesky, A simple salting out procedure for extracting DNA from human nucleated cells, Nucleic Acids Research 16 (1988), 1215.

[30] R.H. Reeves, L.L. Baxter and J.T. Richtsmeier, Too much of a good thing: mechanisms of gene action in Down syndrome, Trends in Genetics 17 (2001), 83-88.

[31] S.J.Wheelan, D.M. Church and J.M. Ostell, Spidey: A Tool for mRNA-to-Genomic Alignments, Genome Research 11 (2001), 1952-1957.

[32] The UniProt Consortium, The Universal Protein Resource (UniProt), Nucleic Acids Research 36 (2008), D190-D195.

[33] T.R. Oliver, E. Feingold, K. Yu, V. Cheung, S. Tinker, M. Yadav-Shah, N. Masse and S.L. Sherman, New insight into human nondisjunction of chromosome 21 in oocytes, PLOS Genetics 4 (2008), e1000033. 


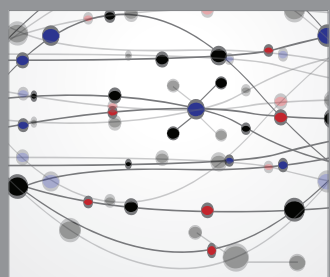

The Scientific World Journal
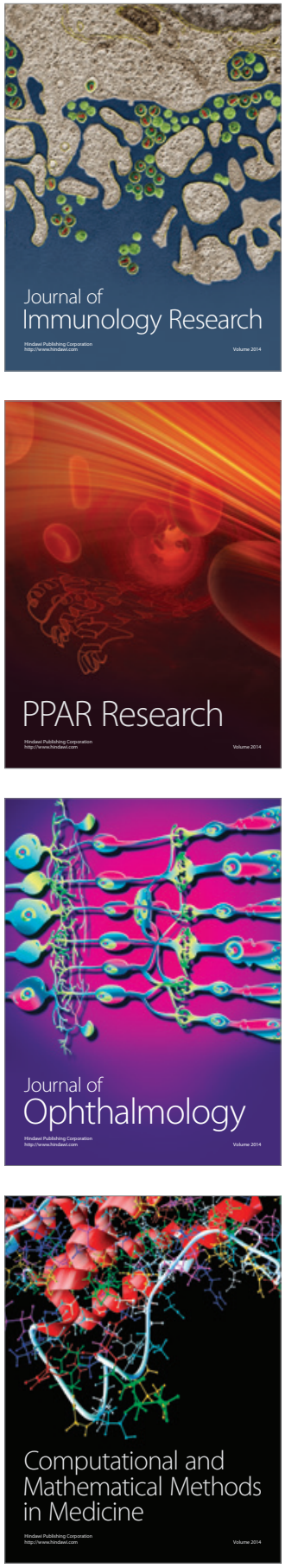

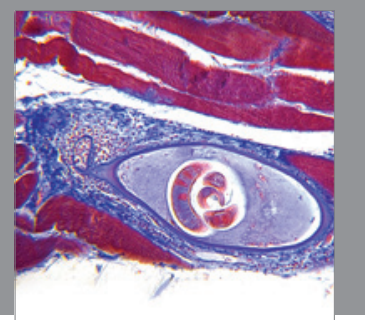

Gastroenterology

Research and Practice
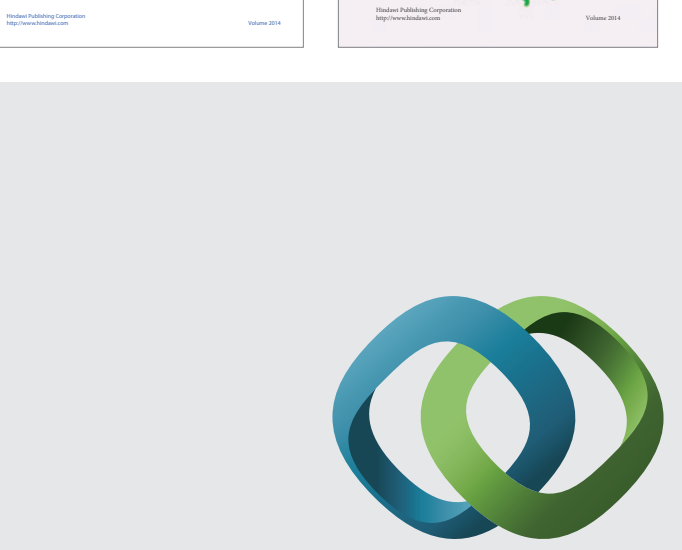

\section{Hindawi}

Submit your manuscripts at

http://www.hindawi.com
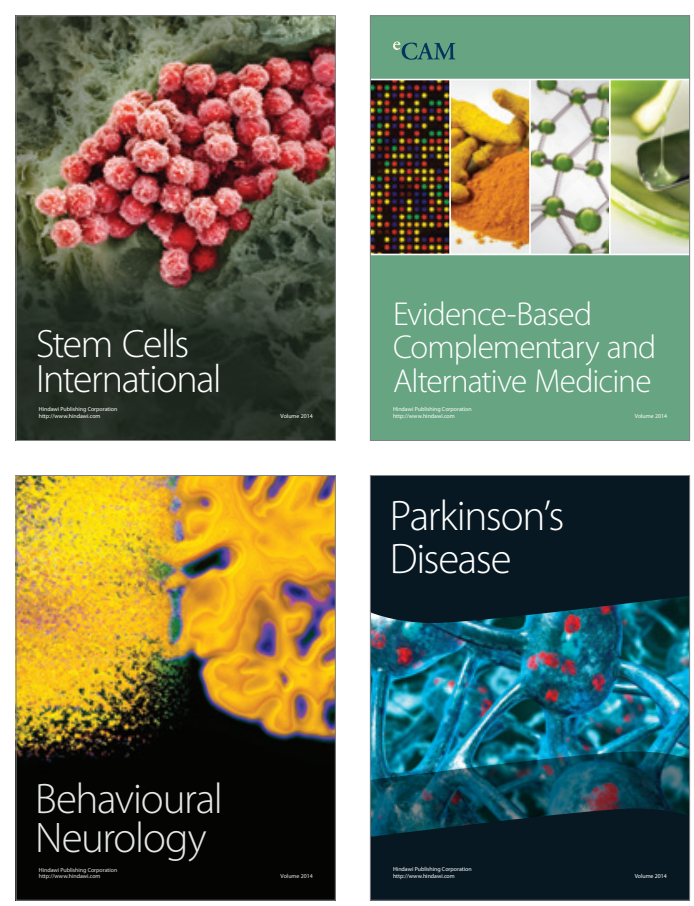

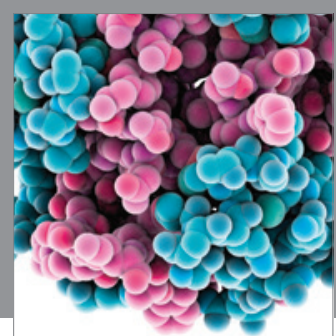

Journal of
Diabetes Research

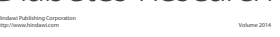

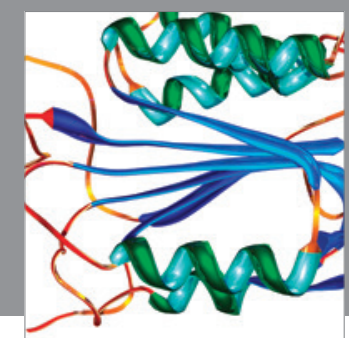

Disease Markers
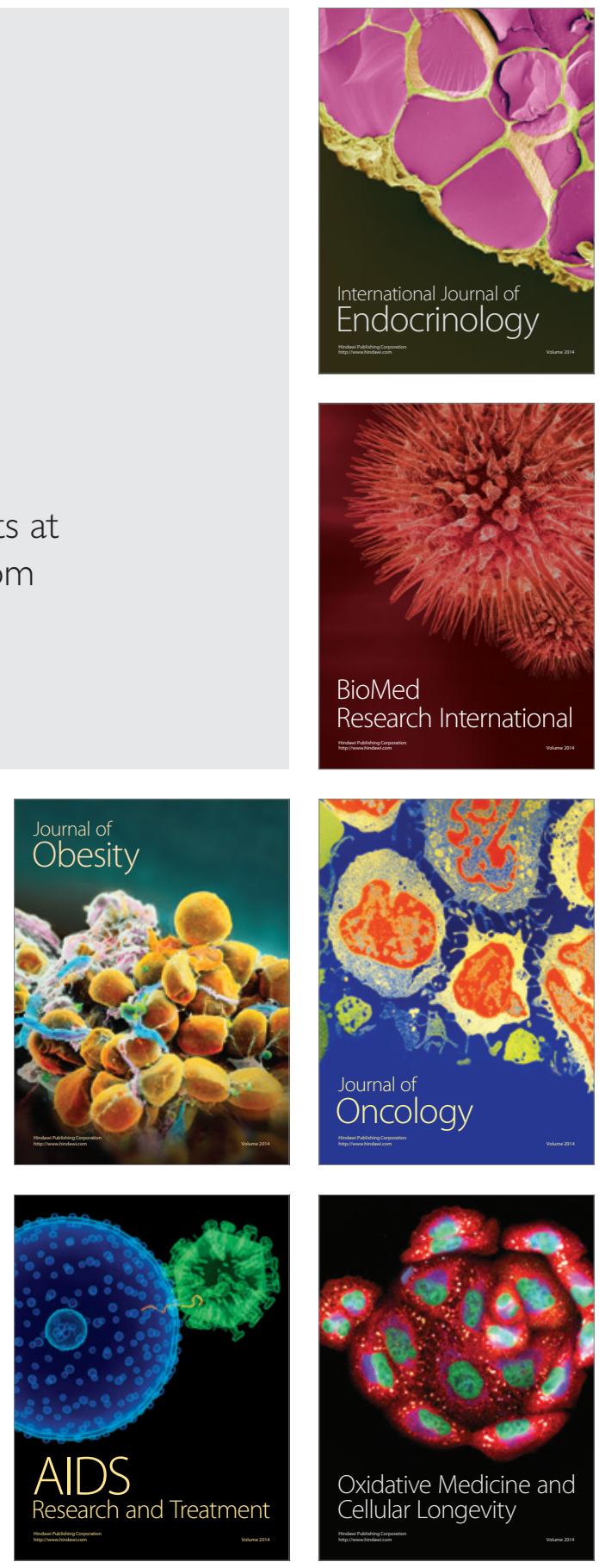